\title{
Sustainability cues on packaging: the influence of recognition on purchasing behavior
}

\author{
by Rees, W., Tremma, O. and Manning, L.
}

Copyright, Publisher and Additional Information: This is the author accepted manuscript. The final published version (version of record) is available online via Elsevier.

This version is made available under the CC-BY-ND-NC licence:

https://creativecommons.org/licenses/by-nc-nd/4.0/legalcode

Please refer to any applicable terms of use of the publisher

DOI: https://doi.org/10.1016/j.jclepro.2019.06.217 

Sustainability cues on packaging: the influence of recognition on purchasing behavior William Rees ${ }^{1}$, Ourania Tremma ${ }^{1}$ and Louise Manning ${ }^{2 *}$ ${ }^{1}$ Harper Adams University, Newport, Shropshire, TF10 8NB

\author{
${ }^{2}$ Royal Agricultural University, Cirencester, Gloucestershire, GL7 6LS
}

\title{
*Corresponding author email: louise.manning@ rau.ac.uk
}

\section{Abstract}

The aim of this research was to examine United Kingdom (UK) consumers' recognition levels, insinuated purchasing intention (IPI) and insinuated purchasing behavior (IPB) associated with sustainability cues on packaging. Empirical research was conducted using an online questionnaire $(\mathrm{n}=254)$ to determine the level of recognition and reported influence of 13 different sustainability cues. The data was analyzed using IBM SPSS Statistics version 24 . The conversion of sustainability cue recognition ( $24 \%$ to $97 \%$ of respondents depending on the cue) to actual IPB was shown in this study to be cue specific and low at $10 \%$ or less except the Fairtrade logo at $22 \%$. Statistically significant differences within the sample population were observed for recognition by age, income and education and for IPB by income and education $(\mathrm{p}<0.05)$ but again this was cue specific. Four distinct consumer clusters were identified with income being a differentiating factor for the cluster with high awareness and high IPI. The research contributes to a wider understanding of the use of sustainability cues the level of consumer recognition and the level of influence on purchasing behavior. The research demonstrates the weak translation of recognition of sustainability cues through to intended sustainable purchasing behavior.

\section{Highlights}


- Packaging cues are a means of communication to consumers.

- Study reflects on use and effectiveness of sustainability cues on packaging.

- Conversion of cue recognition to driving purchasing behavior is low.

26 Keywords sustainability; cues; packaging; behavior; intention; ranking

27 Research paper

28

29 


\section{Introduction}

The definition of sustainability differs depending on the context in which it is used. In its broadest sense, the Oxford Dictionary defines sustainability as "the ability to be maintained at a certain rate or level" (Oxford Dictionary, 2017). Some stakeholders use the term "sustainability" to describe environmental objectives only, whilst others incorporate the environment, economy and society into a construct that forms the 'three pillars of sustainability' (Strange and Bayley, 2008). Agri-food systems are the activities and sociotechnical governance mechanisms that frame the way food is grown, produced, manufactured, retailed and eaten. These activities and governance structures interact and influence at multiple levels not only the methods that are used to produce food, but also the environmental and social impact of such production. Agri-food production is therefore influenced by internal supply chain factors such as production method, resource use and land quality and also by a range of external factors including production intensification, globalization, climate change and scarcity of natural resources and need to support the future demands of a growing global human population (Godfray and Garnett, 2014; Hubeau et al. 2017). Estimates suggest that agri-food systems contribute up to $30 \%$ of global greenhouse gas (GHG) emissions, and account for $70 \%$ of global freshwater use (Ridoutt et al. 2017) creating a moral obligation for food manufacturers and retailers to reduce these effects. However the absence of meaningful information about consumer perceptions of sustainable food in the literature, limits opportunities for market based policy levers via consumer purchasing behaviour, to reduce the impact of agri-food systems in practice (Lim, 2015). The aim of this research is to examine United Kingdom (UK) consumers' recognition levels, insinuated purchasing intention (IPI) and insinuated purchasing behavior (IPB) associated with sustainability cues on packaging. Three specific research questions are considered: firstly what is the level of consumer recognition of packaging sustainability cues and what factors influence the degree of 
recognition; secondly how do sustainability cues influence purchasing intention and finally what is the influence of sustainability cues on purchasing behaviour. In a context of climate change and environmental depletion and degredation, influencing behavioural change that reduces an individual's, community and global environmental impact of food consumption is a critical topic. Our contribution in this research is to seek to identify the nuanced cognitive process of recognition of sustainability cues through to declaring purchasing intention and reported purchasing behaviour. The paper is structured as follows: section 1 is an introduction to the topic; section 2 considers current literature on sustainable purchasing and the influence of sustainability cues; section 3 outlines the materials and methods used; section 4 the results and analysis; section 5 the discussion and section 6 the conclusion of the paper.

\section{Literature Review}

\subsection{Extrinsic sustainability characteristics}

Extrinsic sustainability characteristics reflect the nature of the production standards and systems employed to produce a food e.g. aspects of animal welfare, environmental impact or worker welfare standards (Magnier et al. 2016). Social aspects such as food security and affordability, environmental aspects of the negative externalities of food production that are not addressed within the price paid by the consumer, and economic aspects of profitability and economic resilience for individual businesses, and the supply chain as a whole, are also all of importance (Grunert et al. 2014). Hubeau et al. (2017) notes that academic literature on food sustainability mostly focuses on environmental impacts, while social dimensions receive less attention. When sustainability is interpreted in a broader sense, as for example in an organisation's mission statement, it is often communicated as delivering sustainable value for all stakeholders. However, it becomes apparent that food products cannot be truly sustainable, nor deliver value to consumers without providing health benefits too so when all production 
aspects are considered, this rationale presents a challenge in that healthier, nutrient rich foods, are not necessarily more environmentally sustainable than the energy dense alternatives. Fruit and vegetables are more nutrient rich than processed foods, but because they are perishable, they require cold-chain transportation and storage increasing the energy consumption and environmental impact of their journey from field to retail shelf (Yang et al. 2017). Thus reducing environmental impact and maintaining the ecology and biodiversity of land is not always integrated with the processes of managing the quality and nutritional value of foods that are in turn resource intensive (Horton et al. 2016). This creates a contested space when food manufacturers and retailers then seek to promote the sustainable credentials of a given product.

\subsection{Perceptions of sustainability labeling}

Packaging enhances consumer perceptions of the sustainability and quality of the product (Silva et al. 2017; Steenis et al. 2017) and a key element of that is consumer perception of sustainability labeling. Sustainability labeling allows consumers to consider visual cues that relate to environmental, social and ethical considerations, or alternatively indirectly inference can be drawn from other extrinsic product characteristics such as country of origin, method of production or provenance (Grunert et al. 2014). Third-party certification (TPC) provides assurance that such cues are associated with a set of defined private standards that are routinely verified at steps in the supply chain to ensure integrity of use (Deaton, 2004). This "green" marketing approach seeks to drive consumer behavioral change via the use of pro-social signals and cues to emphasize the societal and/or environmental benefit associated with a given purchasing behavior (Lim, 2015).

Sustainability cues, when recognised, are strong drivers of purchase intention towards food (Chekima et al. 2016). They can increase the perception of the environmental and social benefits associated with a product (Lazzarini et al. 2017), quality, naturalness and freshness (Magnier et al. 2016; Samant and Seo, 2016; Schaufele and Hamm, 2017; Steenis et al. 2017) 
and a preference for national sourcing (Lazzarini et al. 2017). Indeed the value of such sustainability cues is often limited without TPC (Chkanikova and Lehner, 2015). While consumer purchasing behaviour is a major influence (Smith, 2007; Jansson et al. 2017; Hubeau et al. 2017), some suggest that the adoption of sustainable practices is almost exclusively dependent on the degree of enforcement of environmental standards by government and regulators (Chkanikova and Mont, 2015; Mzembe et al. 2016; Rueda et al. 2017). In other words, food manufacturers and retailers adopt 'green' practices not to win customers, but instead as a means to deliver legal compliance. Nevertheless, the enhanced purchase intention in environmentally conscious customer groups is a valuable 'side effect' of sustainable production and an opportunity to capture value for the brand owner and/or retailer.

Sustainability is seen by some as being embodied in organic methods of food production, but Tasca et al. (2017) suggest that this perception might be incorrect as when investigating organic and conventional farming methods for endive, they found no significant difference in overall environmental impact. Indeed, they suggest that the adoption of organic farming led to greater acidification and terrestrial eutrophication. This work concurs with Tuomisto et al. (2012) who assert that organic systems use $84 \%$ more land, and can result in higher ammonia emissions and nitrogen leaching per product unit when compared to conventional agriculture. However other studies identified respectively that organic production of olives and beef produced lower GHG emissions when compared to conventional agriculture (Casey and Holden, 2006; Kaltsas et al. 2007). Traditionally, intrinsic quality characteristics define the size, shape, color, taste, smell, length, freshness, and the inherent nature of a food (Luning et al. 2002; Manning and Luning, 2018). Heavy metal content or pesticide residues, for example, are negative intrinsic characteristics, representing weak social sustainability aspects around the safety of the food, and also poor environmental sustainability aspects in terms of the custodianship of the planet. Some studies suggest that intrinsically, organic food is more 
nutritionally beneficial (Worthington, 1988; Rosetto et al. 2013), but others have suggested that genotype can influence the variation in phytochemical content in organically and conventionally grown (Picchi et al. 2012; Manning and Monaghan, 2019). This contradictory discourse on organic production (D'Evoli et al. 2016; Średnicka-Tober et al. 2016; Stevenson et al. 2018), if consumers are aware of it, could lead to a confused attitudinal and behavioral purchasing response.

Thus, there can be multiple meanings of sustainability creating the potential for opacity or ambiguity in terms of messaging on packaging. Indeed, Yates-Doerr (2015) identifies this as "the opacity of reduction" i.e. the pretence of simplicity that ultimately leads to greater consumer confusion. Opacity weakens product value especially if a reductionist methodology takes multiple sustainability datasets and subsumes them into a single metric or cue (Roos et al 2015). In this context, the use of sustainability cues is worthy of wider exploration to determine its efficacy in practice and what factors influence pro-social consumer intentions and purchasing behavior. Indeed, the binary nature of the characteristics of sustainability: good versus bad; tangible or abstract aspects; or quantifiable or non-quantifiable aspects can allow a multiplicity of consumer perceptions and decisions. Further decisions with regard to sustainable purchasing can be based on both objective (factual) and subjective (emotions and feelings) viewpoints. Thus if the individual's cognitive decision process from recognition, to intention through to intended behaviour is to be more widely understood then research such as that described in this paper will provide a valuable contribution.

\subsection{Factors influencing perception of sustainability cues}

Perception of sustainability cues is affected by consumers' lack of knowledge (McCarthy et al. 2016). In one study, 56\% of participants failed to judge accurately the packaging's recyclability, whilst still being willing to choose the more sustainable food option (Lindh et al. 2016). Further, customer perception of sustainability is strongly affected by 
graphical packaging cues, even if the standards they relate to do not actually reduce environmental impact (Steenis et al. 2017). Another variable that can affect the influence of consumer perception on sustainability cues is general informational context. Exposure to environmental advertising positively predicts the purchasing intention for sustainable food products, while actual environmental knowledge does not produce such an effect (Chekima et al. 2015). Positive consumer perception of sustainability cues is reinforced by social media (Stevens et al. 2016). Indeed experiencing social pressure from peers can explain intentions to purchase, despite individuals exhibiting negative personal attitudes (Vermeir and Verbeke, 2008).

The literature on the recognition of sustainability cues varies. A large body of research conducted across multiple countries including the UK, Greece, Belgium and Canada focuses on organic cue recognition and throughout these studies recognition was low (Campbell et al. 2010; Loo et al. 2013; Gerrard et al. 2013; Anastasiou et al. 2017). Low recognition was shown too by Ellis et al. (2009) and more recently, Soon and Wallace (2018) showed low recognition levels with RSPCA Assured (formerly Freedom Foods) having the highest recognition (41.5\% of respondents), Rainforest Alliance (38.2\%), Red Tractor (37.2\%) and Soil Association $(32.1 \%)$. However, in this study, the names of the standards were given to respondents, rather than the visual packaging cue (logo).

Demographic factors influence consumer attitudinal and behavioral response to sustainability cues. Females' purchase intention positively correlates with responsiveness to 'green' advertising (Meyer-Hofer et al. 2015; Chekima et al. 2016). However, there was also evidence that male customers are more likely to buy 'green' products, while females prefer to purchase organic food (McCarthy et al. 2016). These studies established a geographic influence too. In Germany and Malaysia there was a prevalence of females being sustainable customers, while in China the opposite was the case. In their study in the Netherlands, Verain et al. (2016) 
concluded that being a sustainable consumer was not influenced by gender, age income or education. Considering this contested evidence, investigating the impact of gender on sustainable food consumption specifically in the UK context would therefore be useful. The term "sustainable food consumer" is also difficult to draw out as many sources focus on the purchasing behaviour rather than the individual. A sustainable consumer has been described as an individual who recognises the reasons for specific behaviours that can benefit society and the environment (Wróblewski \& Dacko-Pikiewicz, 2018). Thus an individual who is a sustainable consumer should recognise and then attitudinally and behaviorally respond to sustainability cues. The impact of income on responsiveness to sustainability cues is inconsistent across studies (Chekima et al. 2016; McCarthy et al. 2016), while the positive impact of higher education levels is reported more frequently. A comprehensive approach to constructing the demographic profile of a dedicated sustainable food consumer was taken by Meyer-Hofer et al. (2015). The researchers concluded:

"Convinced sustainable consumers [CSC] are more often female than male and perceive that their personal purchase decision has an impact on overall sustainable development. They show a higher willingness to increase sustainability through their consumption behavior. They are very much interested in high food quality and are not as much influenced by advertisements and offers in their purchase decision making as convinced conventional consumers." (Meyer-Hofer et al. 2015, p.1082). The implications of this finding for food marketers are twofold. Firstly, CSC are strongly interested in food quality in its totality as well as sustainability. Secondly, CSC are less responsive to advertising (Meyer-Hofer et al. 2015), which means that other factors may play a stronger role. In summary, the topic of the influence of sustainability cues is an important, contested and complex issue. Consumer behavior towards sustainability cues is influenced by many factors such as age, income, education and gender, knowledge, information and 
recognition levels. While there is evidence that consumers can misinterpret sustainability cues (Lindh et al. 2016), other studies demonstrate that higher levels of knowledge do not alter consumer perceptions significantly (Chekima et al. 2015; Samant and Seo, 2016) i.e. that there is a weak relationship between recognition and its effect on purchasing behavior. Therefore, further research is required to understand UK consumers' recognition, purchasing intention and purchasing behavior towards sustainability cues, to understand the cognitive process more clearly and the moderating effect of demographic variables such as gender, age and education and income levels.

\section{Materials and Methods}

An explorative, mono-method collected quantitative data via an on-line questionnaire (Bristol Online Survey), with a non-probability convenience sampling approach to distribute the link via online forums and networks. The reason for choosing this method was that the variables identified in the literature could be re-examined in the UK context and that a deductive approach could then be assured through the design of the questions in the survey. Ten hard copy versions were also distributed to recipients above the age of 75 to extend the demographic profile. The questionnaire was live for one month in March 2018 and received 254 responses. The questionnaire consisted of 18 closed questions divided between three parts; 1) Cue motivations; 2) Cue importance; and 3) Demographics (four questions to determine gender, age, education and income) and one aspect of the overall research is presented here (Parts 1 and 3). Part 1, via the question "In the next week, how likely are you to purchase a food product with one of the following labels on the packaging? Please click the statement that best reflects your answer" asked respondents to consider a range of visual cues with no accompanying text or explanation. The visual cues themselves were used as this approach meant that visual recognition could be determined. Part 1 contained the visual cues (Figure 1) 
and ranking questions with a seven-point Likert-style rating scale from do not recognize ("No recognition") through to level of intention to purchase from low ("Would not use") to extremely likely to purchase ("Would use " representing SCS). There was no neutral response to reduce a neutral bias and to reduce the potential for cognitive dissonance and social desirability bias, the term 'sustainability' was not used in the questionnaire.

\section{Take in Figure 1}

The questionnaire was piloted $(\mathrm{n}=10)$ and Part 1 adjusted to the question above based on the feedback provided. Figure 1 shows the visual cues used in the study, but text has been provided therein as a means to underpin the rationale as to why the range of cues and specific cues were chosen. This was not provided to the respondents. The research reported here sought to address the following three research questions:

\section{RQ1: What is the level of consumer recognition of sustainability cues on packaging and what factors may influence this?}

\section{RQ2: What is the insinuated influence of sustainability cues on insinuated purchasing intention (IPI)?}

\section{RQ3: What is the influence of sustainability cues on insinuated purchasing behavior (IPB), are there CSC and if so which cues are of interest to them?}

The data collected from the questionnaire was analyzed using SPSS v24. Descriptive analysis via frequencies and cross-tabulation tests were supported by the $\chi^{2}$ test, Spearman rank correlation and Mann Whitney tests. In order to classify the sample into different respondent segments, a two-step cluster analysis was then conducted. The use of a convenience sampling method is a major limitation of this study. Therefore care has been taken to ensure that the results are not over generalized. In this study, as with many approaches that use this type of 
methodology, no actual behavioral observations were made therefore any conclusions drawn reflect insinuated rather than actual behavior of the respondents.

\section{Results and analysis}

\subsection{Demographic profile}

The demographic profile of the questionnaire participants $(n=254)$ has been collated (Table 1) and shows a large female skew (70.1\%) compared to males $(29.9 \%)$ whereas the UK population is $50.8 \%$ and $49.2 \%$ male (ONS, 2017). Participants aged 18-24 formed the largest group within the sample population (36.6\%) followed by the $45-54$ group (19.3\%) with only $3.1 \%$ of the sample representing $>65$ years. Previous research has demonstrated that using online questionnaires as a research methodology limits reach to the older age demographic (Wright, 2005). Over $66 \%$ of the participants had a bachelor's degree or higher indicating that the sample population of this study were educated, with $79.5 \%$ of participants having a personal annual income of less than $£ 40,000$ which just over one quarter earning less than $£ 10,000$ per annum. The median income category for this study was $£ 20,000$ - 229,999 and correlates with the median UK household income for 2017 of $£ 27,200$ (ONS, 2018).

\section{Take in Table 1}

\subsection{RQ1: What is the level of consumer recognition of sustainability cues on packaging and what factors may influence this?}

The level of cue recognition was assessed for all participants (Table 2). The Fairtrade cue was the most recognized cue (99.6\%), with the "5-a-day" cue (94.9\%) and then the Red Tractor cue (91.3\%). The UTZ cue was the cue least recognized by the participants $(23.6 \%)$. The results are then differentiated by gender (Table 2). Males showed full recognition of the Fairtrade cue, Red Tractor and "5-a-day" cue (93.4\%) and the Rainforest Alliance (90.8\%) with 
the UTZ cue the least recognized at (27.6\%). Female responses were similar in that recognition of the Fairtrade cue was (99.4\%), "5-a-day" cue (95.5\%), Red Tractor (90.4\%) with the UTZ cue the least recognized at $(21.9 \%)$.

\section{Take in Table 2}

All respondents had lowest recognition of the same three cues; UTZ, Best Aquacultural Practices (BAP) and Tesco Nurture. Males had greater recognition of two cues: the Carbon Trust (11\% higher) and Rainforest Alliance (7\% higher) when compared to female participants. The degree, strength and direction of the association between the degree of recognition and demographic factors (gender $\mathrm{H} 1$; age $\mathrm{H} 2$; income $\mathrm{H} 3$; education $\mathrm{H} 4$ ) was tested using $\chi^{2}$ and Spearman rank analyzes (rho value) see Table 3.

\section{Take in Table 3}

A significant association was identified between age and the recognition of the Scotch beef $(\mathrm{p}=0.006)$, Rainforest Alliance $(\mathrm{p}=0.019)$, and Soil Association $(\mathrm{p}=0.000)$ cues. No significant associations were found between age and the recognition of the other nine cues. Using Spearman's rank correlation, the relation between age of participants and the recognition of the Scotch Beef cue has a significant weak, positive correlation (rho=0.211) i.e. as age increases, the level of recognition also increases (but this difference can only be explained by age $(4.5 \%)$ and the rest of the relationship is explained by other factors. The relationship between age of participants and recognition of the Rainforest Alliance cue has a significant weak, negative correlation (rho=-0.172). Therefore, as age increases, the level of recognition of this cue decreases. Variance in the recognition of this cue is explained by change in age (2.9\%), leaving $97.1 \%$ of the relationship explained by other factors. Age and recognition of the Soil Association cue has a significant weak, positive correlation (rho=0.271) i.e. as age 
increases the level of recognition increases. Therefore, changes in the recognition by age is weak leaving the majority of the relationship found explained by other factors.

A significant association was only identified between level of income and recognition of the Soil Association cue $(\mathrm{p}=0.006)$. However a trend was present with Scotch Beef $(p=0.089)$ and Red Tractor $(p=0.071)$ cues, although these were not statistically significant at $p<0.05$. A significant weak, positive correlation ( $\mathrm{rho}=0.214$ ) was shown between income levels and recognition of the Soil Association cue i.e. as level of income increases, the level of recognition also increases, but variance in recognition could only be explained by $4.5 \%$ for income meaning other factors had more influence.

A significant association was only identified between education level and the recognition of the Rainforest Alliance $(p=0.040)$, Tesco Nurture $(p=0.013)$ and the LEAF Marque $(p=0.029)$ cues. A significant weak, negative correlation (rho=-0.186) was shown between education level and recognition of the Tesco Nurture cue i.e. as education level increases, the level of recognition decreases, but $96.6 \%$ of the factors that affect recognition here are explained by other factors. The recognition levels shown in this study were higher than previous studies (Ellis et al. 2009; Soon and Wallace 2018) and this should be considered when results on buying intention and purchasing behavior are now analyzed.

\subsection{RQ2: What is the insinuated influence of sustainability cues on IPI?}

Respondents were asked to confirm the influence of the cues on IPI. The results are presented in Table 4. Female participants reported to be more influenced than the males in terms of IPI by nine of the thirteen sustainability cues. The Red Tractor cue has the highest level of reported IPI (80.3\%). Female participants IPI for the RSPCA cue (60.7\%) was higher than males (40.8\%). Male participants IPI was influenced more by the Carbon Trust and BAP cues, but although $46.1 \%$ of males recognized the Carbon Trust cue only $14.5 \%$ stated IPI 
based on the presence on the cue on a food label. Indeed, 93.4\% of males stated they recognized the 5-a-day cue but only 53.9\% reported it would influence IPI. Interestingly, the BAP cue had the closest recognition and IPI levels for males (recognition 35.5\%; IPI 25.0\%) and females (recognition 33.7\%; IPI 19.1\%). This shows that for many cues the translation from recognition to IPI was limited. Sustainability cues have been suggested as strong drivers of purchasing intention towards food (Chekima et al. 2016) especially if they are linked to TPC (Chkanikova and Lehner, 2015). Xiao et al. (2019) suggests that perceived emotional value affects purchasing intention and "green" practices have been said to influence consumer emotional attachment to a brand (Jang et al. 2015) and it could be argued here to a specific cue. Thus perceived emotional value and personal emotional attachment could be of influence here in how some cues were favored over others.

\subsection{RQ3: What is the influence of sustainability cues on IPB, are there CSC and if so} which cues are of interest to them?

The influence of sustainability cues on IPB (Table 5) shows the dynamic between recognition, IPI and IPB where IPB reflects those individuals who report as CSC. Females reported more IPB based on sustainability cues than males for seven of the thirteen cues, but it should be noted that this was a small sample population and for six of the thirteen cues where IPB was reported it was by $1.3 \%$ of respondents or less. Whilst some found no gender influence on sustainable purchasing behavior (Verain et al. 2016) others state that females are more likely than males to be CSC (Meyer-Hofer et al. 2015). McCarthy et al. (2016) found that females more likely to purchase certified organic foods $(p=0.03)$ and male customers are more likely to purchase 'green' products ( $p=0.02$ ), so the gender influence might be cue specific. Only three of the sustainability cues considered in this study had IPB reported from more than $10 \%$ of respondents, Fairtrade, "5-a-day" and Red Tractor. Males expressed a higher IPB towards 
Rainforest Alliance, MSC and the "5-a-day" cues, whilst females showed higher IPB towards organic, RSPCA assured, LEAF Marque, Carbon Trust and BAP cues albeit that some positive responses were for a very low proportion of respondents. Due to the small sample size of this study these results are limited in terms of generalizing to the whole population but the differentiation of reported behavior associated with sustainability cues by gender is an area worthy of further research.

\section{Take in Tables 4 and 5}

Considering the cue with the greatest IPB, Fairtrade, whilst, $100 \%$ of males reported recognition of the Fairtrade cue, IPI was reported at $80.3 \%$ but IPB was only $21.1 \%$. This compared with females with recognition (99.4\%), IPI (80.3\%) and IPB at 23.6\%. Interestingly the "5-a-day" cue showed similar recognition and IPI levels but a much lower IPB (males 13.2\%: females $9.0 \%$ ). The degree, strength and direction of the association between the degree of recognition and IPB and demographic factors (gender $\mathrm{H} 5$; age $\mathrm{H6}$; income $\mathrm{H} 7$; education H8). This was tested using $\chi^{2}$ and Spearman rank analyzes (rho value) see Table 6.

\section{Take in Table 6}

A significant relationship was identified between education level and IPB related to the "5a-day" cue $(\mathrm{p}=.001)$ only and this was a significant weak, negative correlation $(\mathrm{rho}=-0.20)$ i.e. as education increases, IPB associated with this cue decreases. A significant association was identified between the income level and IPB associated with the Carbon Trust $(p=0.004)$ and LEAF Marque ( $\mathrm{p}=0.006)$ cues only. The Spearman's correlation test showed no correlation between demographic factors (gender, income, age) and IPB for these cues. However, a trend was present between income level and IPB associated with the UTZ cue $(p=0.085)$ although this was not statistically significant at $p<0.05$. Chekima et al. (2016) in their work found no 
relationship between income level and IPB. No significant association was identified in this study between the gender or age and IPB.

\subsection{Factors that influence being a CSC}

The questionnaire responses were reassessed using three criteria: "Do not recognize it", "Do not use it", "use it". Splitting the responses into these three factors and using $\chi^{2}$ to assess responses gave rise to some interesting results. The results show a statistically significant association between men and women and the cues $(\mathrm{p}<0.001)$ whereby females are more likely to use the RSPCA Assured cue (77.7\% of females would use) than male (22.3\% would use). Indeed females are more likely to use the cue $(60.7 \%)$ than not use it $(18.0 \%)$ or not recognize it $(21.3 \%)$. This compares with men who are more likely not to use the cue (43.4\%) than to use (40.8\%) or not to recognize $(15.8 \%)$. With the Rainforest Alliance cue again people who use it are more likely to be female $(73.1 \%$ of females would use) than male ( $26.9 \%$ of males would use) and this is statistically significant $(\mathrm{p}=0.032)$. Both males and females are more likely to use the cue than not to recognize it or use it (Table 7).

\section{Take in Table 7}

With regard to age, there was a statistically significant association by age with regard to those people who use Scotch Beef as a sustainability cue $(\mathrm{p}=0.04)$ see Table 8 . People who used Scotch Beef as a sustainability cue were statistically more likely to be in the age group $18-34(37.6 \%)$ than the 35-54 age group (36.5\%) than over 55 years $(25.9 \%)$. The age group 18-34 were more likely not to recognize the cue $(46.5 \%)$ than to recognize the cue or use $(25.2 \%)$, or not use it $(28.3 \%)$. The age group $35-54$ were more likely to report that they recognized and used the cue $(39.2 \%)$ than to not recognize it $(24.1 \%)$, or to recognize it and not use it (36.7\%). The group over 55 were more likely to use the cue $(45.8 \%)$ than to not use it $(29.2 \%)$ or not recognize it $(25 \%)$. Age also influenced the reported use of the Soil 
393 Association cue $(\mathrm{p}<0.0001)$ where those more likely to use the cue are $18-34$ year olds 394 (37.7\%), compared with 35-54 year olds (34.9\%) and over 55 (27.4\%). However, within the

395 18-34 age group they were more likely not to recognize the cue (40.9\%) than to recognize and not use it $(27.6 \%)$ or recognize and use it (31.5\%). Recognition was much stronger in the $35-$ 54 age group with recognition but not using the cue (43\%) being lower than those who would recognize and use the cue $(46.8 \%)$ compared to no recognition (10.1\%). Again recognition was high in the over 55 age group with use of the cue $(60.4 \%)$ being higher than recognition but not using (25\%) and no recognition being (14.6\%). For the BAP cue those who are more statistically likely to use the product to inform purchase $(\mathrm{p}=0.041)$ are in the $18-34$ age group (47.2\%) compared to the 33-54 age group (22.6\%) and over 55 group (30.2\%). However in the 18-34 age group recognition is low with $29.9 \%$ of respondents recognising the cue and less than a fifth (19.7\%) stating they would use it. This trend is found in all age groups and as Table 2 shows overall only around one third of respondents recognized the cue.

\section{Take in Table 8}

Income was not shown to be an influencing factor for most cues (Tables 9). However, with the Soil Association cue people who were in the $£ 20,000$ - $£ 39,000$ personal income bracket were more likely to use this cue ( $40.6 \%$ of those who would buy it) than other income groups $(\mathrm{p}=0.022)$ although in that income category $28.6 \%$ of respondents stated they did not recognize the cue.

\section{Take in Table 9}

Using the Kruskal-Wallis test and considering the demographic influencing factors of age, personal income and education (Tables 10-15) the following sustainability cues showed some interesting results. 


\subsubsection{Soil Association}

418

Age: There is a statistically significant difference $(\mathrm{p}=0.012)$ by age between those people who do not recognize the cue and those who do not use it when purchasing food i.e. people who do not use the cue (Mean rank $=129.02)$ who are older $(35-44)$ compared to those who do not recognize it (mean rank $=95.40)$ who are younger $(18-24)$. As well there is a statistically significant difference $(\mathrm{p}=0.000)$ by age between those people who do not recognize the cue (mean rank $=95.40)$ and those CSC who use it (mean rank $=146.63)$ when purchasing food i.e. people who do not recognize the cue are younger than those who use it. This means that people who use the cue are older (45-54) than those who do not recognize it (18-24).

Income: There is a statistically significant difference $(\mathrm{p}=0.004)$ by income between those people who do not recognize the cue (mean rank $=104.53$ ) and those who use it when purchasing food $($ mean rank $=139.74)$ i.e. people who do not recognize the cue have a lower income (£20,000-£39,999) compared to those who recognize it and use it (£40,000-£74,999).

\subsubsection{Red Tractor}

Age: There is a statistically significant difference $(\mathrm{p}=0.044)$ by age between those people who do not recognize the cue (mean rank $=91.48)$ and those who use it $($ mean rank $=130.40)$ when purchasing food i.e. people who do not recognize the cue are younger (18-24) than those who recognize and use the cue (35-44).

Income: There is a statistically significant difference by income $(p=0.028)$ between those who do not recognize the cue (mean rank $=106.48)$ who are on a lower income $(£ 20,000$ $£ 39,999)$ than those who recognize it but do not use it (mean rank $=148.66$ ) who are of higher income (£40,000-£74,999). 
Education: There was a statistically significant difference $(p=0.008)$ between those who do not recognize the cue, who have a lower educational level (mean rank $=105.64)$, compared to those who recognize the cue but would not use it (mean rank =163.96). Further, a statistically significant difference ( $\mathrm{p}=0.013$ ) was identified between people who would use the cue as a cue (mean rank $=124.85)$ and those who recognize the cue but would not use it (mean rank = 163.96). Results showed that people who would use the cue have a lower education level compared to those who recognize it but would not use it.

\subsubsection{Scotch Beef}

Age: There is a statistically significant difference $(\mathrm{p}=0.001)$ by age between those people who do not recognize the cue (mean rank $=107.31$ ) and those CSC who use it when purchasing food (mean rank $=147.68)$ i.e. people who use the cue are older $(45-54)$ compared to those who do not recognize it who are younger (25-34).

\subsubsection{Rainforest Alliance}

Age: There is a statistically significant difference $(\mathrm{p}=0.013)$ by age between those people who do not recognize the cue (mean rank $=157.58)$ and those who do not use it (mean rank $=$ 116.22) when purchasing food i.e. people who do not use the cue are younger (25-34) whereas those who do not recognize it are older (45-54). As well there is a statistically significant difference $(\mathrm{p}=0.048)$ by age between those people who do recognize the cue (mean rank $=$ 157.58) and those who use it when purchasing food (mean rank $=125.71)$ i.e. CSC are younger (25-34) whereas those who do not recognize it are older (45-54).

\subsubsection{Tesco Nurture}

Education: the data shows that there is a statistically significant difference $(p=0.053)$ between those people who recognize the cue and do not use it (mean rank $=112.56$ ) who have a lower 
educational level compared to those respondents who do not recognize the cue (mean rank $=$ 136.78).

\subsection{6 "5'A'Day"}

465

466

467

468

469

470

471

472

473

474

475

476

477

478

479

480

481

482

Education: there is a statistically significant difference $(p=0.005)$ in terms of education between those people in the sample that recognized but would not use the cue (mean rank = 146.98) who had a higher education level compared to those respondents who recognized the cue and would use it (mean rank =117.83). This finding suggests that people with higher education may have not felt it necessary to use the cue when purchasing food, or alternatively felt that the cue was not demonstrating healthy eating on the products on which it is present. This finding is worthy of further research.

\subsection{Cluster analysis}

In order to classify the sample into different segments, a two-step cluster analysis was conducted (Table 16). The distance was measured through the Log-Likelihood in order to determine the similarity between the clusters. The clustering algorithm determined the optimal number of clusters based on the Akaike Information Criterion (AIC). Four clusters were identified through the two-step algorithm based on the level of consumer recognition of sustainability cues on packaging and the demographics questions including age, gender, education and income. Cluster 1 constitutes the biggest cluster created and included 71 respondents ( $28 \%$ of the total sample) who can be characterized as individuals with low recognition and low IPI level. Cluster 3 included 69 respondents (27.2\% of the sample) who showed mixed cue recognition but where cues were recognized respondents exhibited high IPI. Cluster 4 consisted of 56 consumers $(22.8 \%)$ who showed higher levels of recognition but presented low IPI. Conversely, Cluster 2 included 58 consumers (22\%) who showed both high awareness and high levels of IPI. The most important cues which contributed most to the 
prediction of these clusters are by level of importance: the Soil Association cue (1.00), the LEAF MARQUE cue (0.95), Carbon Footprint cue (0.87), Scotch Beef (0.80), RSPCA Assured (0.72), BAP (0.70) and Tesco Nurture (0.61). This may well be because of the differentiated rate of response already identified when analysing the results of this study i.e. cues that had a high level of recognition across the board such as Fairtrade had less influence on the prediction of clusters.

\section{Take in Table 16}

The clusters are now considered in more detail.

\subsubsection{Cluster 1: Low recognition - Low IPI "Less knowledgeable cue-relative}

consumers"

In Cluster 1, results reflect a low level of recognition of most of the sustainability cues.

The cluster includes respondents with the lowest degree of recognition to cues such as BAP by 95.8\%, the UTZ cue (93.0 \%), the Tesco Nurture (91.5\%) and LEAF Marque cue $(91.5 \%)$.

Moreover, these respondents do not recognize the Scotch Beef (83.1\%), the Carbon Footprint $(80.3 \%)$ or the Soil Association cue $(73.2 \%)$. Noteworthy here is the fact that in this cluster there are no respondents who would use the Tesco Nurture or LEAF Marque cues to influence IPB. This might reflect their usual food retailer of choice. Regarding the levels of recognition for the RSPCA cue, results are mixed with $49.3 \%$ of the respondents not recognizing the cue and $50.7 \%$ recognize it. Respondents that did indeed recognize the cue would either use it $(28.2 \%)$ or would not choose to use it $(22.5 \%)$. The highest level of recognition along with the highest IPIs in this cluster were observed for the Fairtrade and the 5-a-Day cues, where respondents would predominantly use them by $70.4 \%$ and $64.8 \%$ respectively. The same respondents would use Red Tractor (63.6\%) and the MSC cue (45.1\%) leaving $20 \%$ and $36.6 \%$ 
recognized by these respondents but has the lowest IPI since $36.6 \%$ of these respondents would not use it.

The demographics of the respondents who compose cluster 1 , show that $61 \%$ are women (men 39\%). The educational level of this cluster is mainly undergraduate $(57.7 \%)$ then secondary $(29.5 \%)$ and to a lesser extent postgraduate (12.8\%). Additionally, cluster 1 has a high proportion of consumers who belong in the age group of 18-25 (78.9\%) while the income of the consumers is between $£ 0-19,999$ (45.1\%) and $£ 20,000-£ 39,999(35.2 \%)$.

\subsubsection{Cluster 2: High recognition and high IPI "Convinced sustainable consumers} (CSC)"

Cluster 2 is composed of 58 respondents $(22.8 \%)$ out of the total number in the survey. These consumers can be characterized as CSC since the level of awareness in this group is very high as well as the IPI for a given cue. The highest level of recognition/was for the RSPCA, MSC, Soil Association, Red Tractor, Fairtrade and 5-a-Day cues at 100\%. Moreover, consumers in Cluster 2 recognized at a high level the following cues -arranged in descending order from the highest recognition to the lowest level of recognition: Rainforest Alliance (96.6\%), Scotch Beef (86.2\%), Carbon Footprint (84.5\%), LEAF Marque (84.5\%), BAP (62.1\%), Tesco Nurture (58.6\%) and UTZ by (39.7\%). As for the reported IPI based on the cues, results showed that in this cluster respondents would use the cues as follows: Fairtrade (98.3\%), the MSC cue (93.1\%), Red Tractor (91.4\%), Rainforest Alliance (91.4\%), RSPCA Assured (84.5\%), Soil Association (79.3\%), 5-a-Day (65.5\%), LEAF Marque (62.1\%), Scotch Beef (55.2\%), BAP (51.7\%) and Carbon Footprint (44.8\%).The CSC cluster is mainly represented by female at $60.3 \%$ who belong to the age group $35-54$ and primarily have a postgraduate educational level (36.2\%). Regarding the income of this group, consumers are mainly of the highest income level of $£ 75,000$ and over. 
Cluster $3(n=69)$ contained respondents with the following cue recognition levels Fairtrade (100\%), 5-a-Day (92.8\%), Red Tractor (88.4\%), MSC (84.1\%), Rainforest Alliance (82.6\%),

Soil Association (82.6\%), RSPCA Assured (79.7\%) and Scotch Beef (69.6\%). Respondents exhibited low levels of recognition for the LEAF Marque cue at 33.3\%, BAP (21.7\%), Tesco Nurture (17.4\%), UTZ (7.3\%) and Carbon Footprint (2.9\%). IPI proved to be high for the cues that the respondents recognized. Specifically, respondents in cluster 3 would use the Fair-Trade cue $(92.8 \%)$, Red Tractor (84.1\%), MSC (79.7\%), RSPCA Assured (76.8\%), Rainforest Alliance (73.9\%), 5-a-Day (63.8\%), Soil Association (59.4\%) and Scotch Beef (50.7\%). Lower intention to purchase a product based on the cues was observed for LEAF Marque (27.5\%), BAP (20.3\%) and Tesco Nurture (10.1\%); UTZ (1.45\%) and Carbon Footprint (0.0\%). age group 18-34 (36.2\%). Moreover, these consumers have an undergraduate educational level (47.8\%) and belong to the income scale of $£ 20,000-£ 39,999$ (52.17\%).

\subsubsection{Cluster 4: Aware - Low IPI "Unconvinced purchasers"}

Cluster 4 consists of 56 respondents (22\% of the sample population). The main characteristic of this cluster is that respondents who belong to this group are aware of sustainability cues but have low IPI for the cues assessed here. Specifically, respondents showed 100\% recognition of the following cues: FairTrade, Red Tractor, MSC, and 5-a-Day. Moreover, they reported high levels of recognition for the RSPCA Assured cue (98.2\%), Soil Association (96.6\%), Scotch Beef (96.4\%), Rainforest Alliance (96.4\%), LEAF Marque 
level of recognition was for the UTZ cue where $51.8 \%$ of respondents did not recognize it. The lowest IPI for these respondents was for the UTZ cue (0\%), Carbon Footprint (1.8\%), Tesco Nurture (3.6\%), LEAF Marque (7.1\%), BAP (12.5\%), Soil Association (21.4\%), Scotch Beef (26.8\%), Rainforest Alliance (28.57\%), and RSPCA Assured (37.5\%). On the contrary, the highest IPI in descending order was the Red Tractor cue $(85.7 \%)$, FairTrade $(58.9 \%)$, and the MSC and 5-a-Day cues both $51.8 \%$ respectively. Cluster 4 is composed mainly of female $(66.07 \%)$ and the age group that dominates is the $18-34(42.85 \%)$. Respondents are primarily of secondary education $(42.85 \%)$ and the income they represent is that of $£ 0-19,999(35.7 \%)$.

\section{Discussion}

This research examined the cognitive process of recognition or not of particular sustainability cues through to IPI and then IPB. The study found a high level of recognition of the sustainability cues examined with eight of the thirteen cues being recognized by more than $50 \%$ of respondents and the Fairtrade, 5-a-Day and Red Tractor cues being recognized by more than $90 \%$ of correspondents. This finding does not agree with the literature (Ellis et al. 2009; Campbell et al. 2010; Loo et al. 2013; Gerrard et al. 2013; Anastasiou et al. 2017; Soon and Wallace, 2019) that found low recognition. The reasons for this are unclear, but the high levels of recognition in this study did mean that the cognitive process of recognition through to IPB is explored in detail. This study did find four clusters within the respondents where the levels of recognition have been characterised as "low", "aware", "mixed" and "high" showing as expected that a key primary element of nudging sustainable purchasing behavior is recognition. However this work has shown as with other previous work that higher levels of knowledge have a weak relationship with purchasing behaviour (Chekima et al. 2015; Samant and Seo, 2016) so other factors are also of influence. 

Association cue being recognized by older and higher income respondents; Scotch Beef as a cue being recognized by older respondents; Rainforest Alliance being recognized by younger respondents and Tesco Nurture as a cue being recognized less as education level increases. However, where relationships were identified between demographics and recognition the rho value was weak showing a low level of association so there are other factors not tested here that may also have a stronger influence on the findings.

With regard to IPI, female participants reported higher IPI than males for nine of the thirteen sustainability cues. The Fairtrade cue has the highest level of reported IPI $(80.3 \%)$ compared to a recognition response by $99.6 \%$ of all adults. However, the influence of recognition of sustainability cues on IPB is limited. For example, $64.6 \%$ of participants recognize the Scotch Beef cue but less than 5.2\% show IPB with regard to this cue. This research isolated sustainability cues as individual cues and excluded price as a mediating factor so further research using the same cues and introducing the influence of price would potentially provide more insight into the results identified her. Further the nutrition cue "5a-day" only showed limited IPB and this is worthy of further investigation considering the global challenges of non-communicable diseases and the need for a healthy diet. regard to sustainability cues as it identified four distinct clusters within the respondents. These clusters show the role of income whereby those respondents with a high level of recognition and high IPI came from the highest income group and conversely those with a high level of recognition and low IPI came from the low income group in the study. The relationship between recognition of sustainability cues, IPI and IPB has been shown in this study to be nuanced and cue specific. The research was designed to provide insight for 
food businesses and packaging designers who seek to increase the purchasing of "sustainable products".

\section{Conclusion}

The aim of this research is to examine United Kingdom (UK) consumers' recognition levels, insinuated purchasing intention (IPI) and insinuated purchasing behavior (IPB) associated with sustainability cues on packaging. The level of consumer recognition of packaging sustainability cues and the factors that influence the degree of recognition and the degree of translation to IPI and IPB were determined. As a result this study makes a contribution to the consideration of the efficacy of sustainability cues to encourage consumers to be convinced sustainable consumers. Aside from the Fairtrade cue, where the IPB was suggested for one in five of respondents in the study, all other cues showed very low IPB despite high levels of recognition. This study has implications in terms of academic theory and practice. Firstly in terms of academic theory, the limited translation from recognition to IPI to IPB means further qualitative research should be undertaken to contextualize this cognitive process in more detail. The selective nature too of which cues stimulate IPI and which do not could be critiqued in more detail especially the role of single issue cues versus the development of more holistic cues that cover environmental and social aspects of the triple bottom line more fully. This research has practical implications for governments and private organisations using terms of insinuated behaviour change. 
Anastasiou, C., Keramitsoglou, K., Kalogeras, N., Tsagkaraki, M., Kalatzi, I. Tsagarakis, K. 2017. Can the "Euro-Leaf" logo affect consumer's willingness-to-buy and willingness-to-pay for organic food and attract consumers' preferences? An empirical study in Greece. Sustainability, 9(8). 1450 of Canadian consumers of local and organic produce. Horticulture Science, 45(10), 14806341488.

Casey, J. Holden, N. 2006. Greenhouse gas emissions from conventional, agri-environmental scheme, and organic Irish Suckler-beef units. Journal of environmental quality, 35, 231-239.

637 Chekima, B., Wafa, S., Igau, O., Chekima, S. Sondoh, S. 2016. Examining green 638 consumerism motivational drivers: does premium price and demographics matter to green 639 purchasing?. Journal of Cleaner Production, 112(4), 3436-3450.

640 Chekima, B., Chekima, S., Wafa, S., Igau, O. Sondoh, S. 2015. Sustainable consumption: the effects of knowledge, cultural values, environmental advertising, and demographics.

642 International Journal of Sustainable Development and World Ecology, 23(2), 210-220.

Chkanikova, O. Lehner, M., 2015. Private eco-brands and green market development: towards new forms of sustainability governance in the food retailing. Journal of Cleaner

645 Production, 107, 74-84.

Chkanikova, O. Mont, O. 2015. Corporate Supply Chain Responsibility: Drivers and Barriers for Sustainable Food Retailing. Corporate Social Responsibility \& Environmental Management, 22, 65-82.

Deaton, J. 2004. A theoretical framework for examining the role of third-party certifiers. Food Control, 15(8), 615-619.

D’Evoli, L., Lucarini, M., del Pulgar, J.S., Aguzzi, A., Gabrielli, P., Gambelli, L. LombardiBoccia, G., 2016. Phenolic Acids Content and Nutritional Quality of Conventional, Organic and Biodynamic Cultivations of the Tomato CXD271BIO Breeding Line (Solanum lycopersicum L.). Food and Nutrition Sciences, 7(12), 1112.

Ellis, K., Billington, K., McNeil, B. McKeegan, D. 2009. Public opinion on UK milk marketing and dairy cow welfare, 18, 267-282

657 Gerrard, C., Janssen, M., Smith, L., Hamm, U. Padel, S. 2013. UK consumer reactions to 658 organic certification logos. British Food Journal, 115(5), 727-742.

659 Godfray, H. Garnett, T. 2014. Food security and sustainable intensification. Philosophical 660 Transactions of the Royal Society B: Biological Sciences, 369 (1639). NCBI Available from: 661 https://www.ncbi.nlm.nih.gov/pmc/articles/PMC3928882/ [Accessed 15 ${ }^{\text {th }}$ December 2017]. 
662 Grunert, K.G., Hieke, S., Wills, J., 2014. Sustainability labels on food products: Consumer 663 motivation, understanding and use. Food Policy, 44, 177-189.

664 Horton, P., Koh, L. Guang, V.S., 2016. An integrated theoretical framework to enhance 665 resource efficiency, sustainability and human health in agri-food systems. Journal of Cleaner 666 Production, 120, 164-169.

667 Hubeau, M., Marchand, F., Coteur, I., Mondelaers, K., Debruyne, L. Van Huylenbroeck, G. 668 2017. A new agri-food systems sustainability approach to identify shared transformation 669 pathways towards sustainability. Ecological Economics, 131(1), 52-63.

670 Jang, Y. J., Kim, W. G., Lee, H. Y. 2015. Coffee shop consumers' emotional attachment and 671 loyalty to green stores: The moderating role of green consciousness. International Journal of 672 Hospitality Management, 44, 146-156.

673 Jansson, J., Nordlund, A. Westin, K. 2017. Examining drivers of sustainable consumption: 674 the influence of norms and opinion leadership on electric vehicle adoption in Sweden.

675 Journal of Cleaner Production, 154, 176-187.

676 Katlas, A., Mamolo, A., Tsatsarelis, G., Nanos, G. Kalburtji, K. 2007. Energy budget in 677 organic and conventional olive groves. Agriculture, Ecosystems \& Environment, 122, $243-$ 678251.

Lazzarini, G., Visschers, V. Siegrist, M. 2017. Our own country is best: factors influencing consumers' sustainability perceptions of plant-based foods. Food Quality and Preference, 60(1), 165-177.

Lim, W. 2015. A blueprint for sustainability marketing: defining its conceptual boundaries 684

Lindh, H., Olsson, A. Williams, H. 2016. Consumer perceptions of food packaging: contributing to or counteracting environmentally sustainable development?'. Packaging Technology and Science, 29(1), 3-23.

Loo, E., Diem, M., Pieniak, Z. Verbeke, W. 2013. Consumer attitudes, knowledge, and consumption of organic yoghurt. Journal of Dairy Science, 96(4), 2118-2129.

690 Luning, P.A., Marcelis, W.J. Jongen, W.M., 2002. Food quality management: a techno691 managerial approach. Wageningen Pers.

692 Magnier, L., Schoormans, J. Mugge, R. 2016. Judging a product by its cover: packaging 693 sustainability and perceptions of quality in food products. Food Quality and Preference, 694 53(1), 132-142. approaches to an emerging issue, Journal of Horticulture and Biotechnology, 94(4), 413-421 
Manning, L. Luning, P. 2018, Chapter 16: Determining farm derived food safety risk Food safety for the $21^{\text {st }}$ Century: Managing HACCP and Food Safety through the Global Chain, Wallace et al., Wiley Blackwell

McCarthy, B., Liu, H. Chen, T. 2016. Innovations in the agro-food system: adoption of certified organic food and green food by Chinese consumers. British Food Journal, 118(6), 1334-1349.

Meyer-Hofer, M., Wense, V. Spiller, A. 2015. Characterising convinced sustainable food consumers. British Food Journal, 117(3), 1082-1104.

Mzembe, A., Lindgreen, A., Maon, F. Vanhamme, J. 2016. Investigating the Drivers of Produce Limited in Malawi. Corporate Social Responsibility and Environmental Management, 23, 165-178.

ONS (Office of National Statistics). 2017. Overview of the UK population: July 2017. [Online]. Office of National Statistics. Available from: https://www.ons.gov.uk/peoplepopulationandcommunity/populationandmigration/population estimates/articles/overviewoftheukpopulation/july2017 [Accessed 22 ${ }^{\text {nd }}$ April 2018].

ONS (Office of National Statistics). 2018. Household disposable income and inequality in the UK: financial year ending 2017. [Online]. Office of National Statistics. Available from: https://www.ons.gov.uk/peoplepopulationandcommunity/personalandhouseholdfinances/inco meandwealth/bulletins/householddisposableincomeandinequality/financialyearending2017 [Accessed 15 ${ }^{\text {th }}$ April 2018].

Oxford Dictionary. 2017. Definition of sustainability in English. [Online]. Oxford Dictionary. Available from: https://en.oxforddictionaries.com/definition/sustainability [Accessed $13^{\text {th }}$ December 2017]. Phytochemical content in organic and conventionally grown Italian cauliflower. Food Chemistry, 130(3), 501-509.

Ridoutt, B., Hendrie, G. Noakes, M. 2017. Dietary strategies to reduce environmental impact: A critical review of the evidence base. Advances in Nutrition an International Review Journal, 8(6), 933-946.

Roos, E., Karlsson, H., Witthoft, C. Sundberg, C. 2015. Evaluating the sustainability of dietscombining environmental and nutritional aspects. Environmental Science and policy, 47, 157166. 
Rueda, X., Garrett, R. Lambin, E. 2017. Corporate investments in supply chain sustainability: selecting instruments in the agri-food industry. Journal of Cleaner Production, 142(4), 24802492.

Samant, S. Seo, H. 2016. Quality perception and acceptability of chicken breast meat labelled with sustainability claims vary as a function of consumers' label-understanding level. Food Quality and Preference, 49(1), 151-160.

Schaufefe, I. Hamm, U. 2017. Consumer perceptions, preferences and willingness to pay for wine with sustainability characteristics: a review. Journal of Cleaner Production, 147(1), 379-394.

Silva, A., Bioto, A., Efraim, P. Queiroz, G. 2017. Impact of sustainability labelling in the perception of sensory quality and purchase intention of chocolate consumers. Journal of Cleaner Production, 141(1), 11-21.

Smith, B. 2007. Developing sustainable food supply chains. Philosophical Transactions of the Royal Society, 363, 849-861.

Soon, M. Wallace, A. 2018. A greater share of the stomach? Role of provenance and ethical standards on consumer' food choices and purchasing intentions. Nutrition and Food Science, 48(2), 318-323.

Średnicka-Tober, D., Barański, M., Seal, C.J., Sanderson, R., Benbrook, C., Steinshamn, H., Gromadzka-Ostrowska, J., Rembiałkowska, E., Skwarło-Sońta, K., Eyre, M. Cozzi, G., 2016. Higher PUFA and n-3 PUFA, conjugated linoleic acid, $\alpha$-tocopherol and iron, but lower iodine and selenium concentrations in organic milk: a systematic literature review and metaand redundancy analyses. British Journal of Nutrition, 115(6), 1043-1060.

Steenis, N., Van Herpen, E., Van Der Lans, I., Ligthart, T. Van Trijp, H. 2017. Consumer response to packaging design: the role of packaging materials and graphics in sustainability perceptions and product evaluations. Journal of Cleaner Production, 162(1), 286-298.

Stevens, T., Aarts, N., Termeer, C. Dewulf, A. 2016. Social media as a new playing field for the governance of agro-food sustainability. Current Opinion in Environmental Sustainability, 18(1), 99-106.

Strange, T. Bayley, A. 2008. Sustainable Development Linking Economy, society, environment. Paris: OECD publishing.

Stevenson, M.C., Drake, C. Givens, D.I., 2018. Further studies on the iodine concentration of conventional, organic and UHT semi-skimmed milk at retail in the UK. Food chemistry, 239, 551-555. 
Tasca, A. Nessi, S. Rigamonti, L. 2017. Environmental sustainability of agri-food supply chains: an LCA comparison between two alternative forms of production and distribution of endive in northern Italy. Journal of Cleaner Production, 140(2), 725-741

Tuomisto, H., Hodge, I., Riordan, P. Macdonald, D. 2012. Does organic farming reduce environmental impacts? A meta-analysis of European research. Journal of environmental management, 112(2012), 309-320.

Verain, M., Sijtsema, S. Antonides, G. 2016. Consumer segmentation based on food-category attribute importance: the relation with healthiness and sustainability perceptions. Food Quality and Preference, 48(1), 99-106.

Vermeir, I. Verbeke, W., 2008. Sustainable food consumption among young adults in Belgium: Theory of planned behaviour and the role of confidence and values. Ecological economics, 64(3), 542-553.

Vermeir, I. Verbeke, W. 2006. Sustainable food consumption: Exploring the consumer "attitude-behavioral intention" gap. Journal of Agricultural and Environmental ethics, 19(2), 169-194.

Worthington, V. 1998. Effect of agricultural methods on nutritional quality: A comparison of organic with conventional crops. Alternative Therapies in Health and Medicine, 4, 58-69.

Wright, K. 2005. Researching Internet-Based Populations: Advantages and Disadvantages of Online Survey Research, Online Questionnaire Authoring Software Packages, and Web Survey Services. Journal of Computer-mediated communication, 10(3). 1034

Wróblewski, Ł., Dacko-Pikiewicz, Z. 2018. Sustainable Consumer Behaviour in the Market of Cultural Services in Central European Countries: The Example of Poland. Sustainability, 10(11), 3856.

Xiao, L., Guo, F., Yu, F., Liu, S. 2019. The Effects of Online Shopping Context Cues on Consumers' Purchase Intention for Cross-Border E-Commerce

Sustainability. Sustainability, 11(10), 2777.

Yang, M., Evans, S., Vladimirova, D. Rana, P., 2017. Value uncaptured perspective for sustainable business model innovation. Journal of Cleaner Production, 140, 1794-1804.

Yates-Doerr, E., 2012. The opacity of reduction: Nutritional black-boxing and the meanings of nourishment. Food, Culture \& Society, 15(2), 293-313. 
Table 1. Demographic information of questionnaire participants

\begin{tabular}{|c|c|c|}
\hline & Sample Number & Valid Percentage (\%) \\
\hline Total Response & 254 & 100 \\
\hline \multicolumn{3}{|l|}{ Gender } \\
\hline Male & 76 & 29.9 \\
\hline Female & 178 & 70.1 \\
\hline \multicolumn{3}{|l|}{ Age } \\
\hline$<18$ & 0 & 0.0 \\
\hline $18-24$ & 93 & 36.6 \\
\hline $25-34$ & 34 & 13.4 \\
\hline $35-44$ & 30 & 11.8 \\
\hline $45-54$ & 49 & 19.3 \\
\hline $55-65$ & 40 & 15.7 \\
\hline$>65$ & 8 & 3.1 \\
\hline \multicolumn{3}{|l|}{ Education } \\
\hline No education & 3 & 1.2 \\
\hline GCSE & 17 & 6.7 \\
\hline Alevel & 65 & 25.6 \\
\hline Bachelors & 114 & 44.9 \\
\hline Masters & 43 & 16.9 \\
\hline Doctoral & 12 & 4.7 \\
\hline \multicolumn{3}{|l|}{ Income } \\
\hline$<£ 10,000$ & 72 & 28.3 \\
\hline$£ 10,000-£ 19,999$ & 49 & 19.3 \\
\hline$£ 20,000-£ 29,999$ & 49 & 19.3 \\
\hline$£ 30,000-£ 39,999$ & 32 & 12.6 \\
\hline$£ 40,000-£ 49,999$ & 26 & 10.2 \\
\hline$£ 50,000-£ 74,999$ & 15 & 5.9 \\
\hline$£ 75,000-£ 99,999$ & 4 & 1.6 \\
\hline$>£ 100,000$ & 7 & 2.8 \\
\hline
\end{tabular}


Table 2. Sustainability cue recognition

\begin{tabular}{|c|c|c|c|c|c|c|c|c|c|c|c|c|c|}
\hline \multicolumn{14}{|c|}{ All participants } \\
\hline$(n=254)$ & 苞 & & 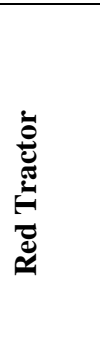 & 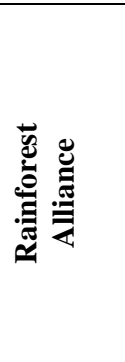 & 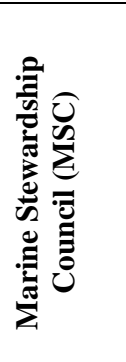 & 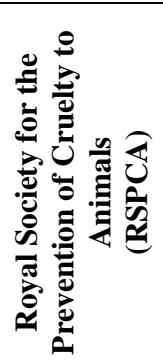 & 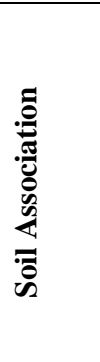 & 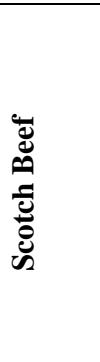 & 递 & 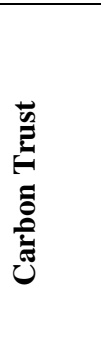 & 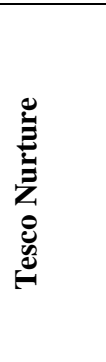 & 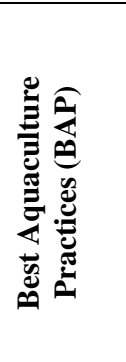 & $\stackrel{N}{S}$ \\
\hline $\begin{array}{l}\text { Percentage that do } \\
\text { recognize }(\%)\end{array}$ & 99.6 & 94.9 & 91.3 & 85.8 & 85.4 & 80.3 & 73.6 & 64.6 & 46.9 & 38.6 & 35.0 & 34.3 & 23.6 \\
\hline $\begin{array}{l}\text { Percentage that do } \\
\text { not recognize }(\%)\end{array}$ & 0.4 & 5.1 & 8.7 & 14.2 & 14.6 & 19.7 & 26.4 & 35.4 & 53.1 & 61.4 & 65.0 & 65.7 & 76.4 \\
\hline \multicolumn{14}{|c|}{ Male respondents $(n=76)$} \\
\hline $\begin{array}{l}\text { Percentage that do } \\
\text { recognize }(\%)\end{array}$ & 100.0 & 93.4 & 93.4 & 90.8 & 86.8 & 84.2 & 73.7 & 63.2 & 51.3 & 46.1 & 36.8 & 35.5 & 27.6 \\
\hline $\begin{array}{l}\text { Percentage that do } \\
\text { not recognize }(\%)\end{array}$ & 0.0 & 6.6 & 6.6 & 9.2 & 13.2 & 15.8 & 26.3 & 36.8 & 48.7 & 53.9 & 63.2 & 64.5 & 72.4 \\
\hline \multicolumn{14}{|c|}{ Female respondents $(n=178)$} \\
\hline $\begin{array}{l}\text { Percentage that do } \\
\text { recognize }(\%)\end{array}$ & 99.4 & 95.5 & 90.4 & 84.8 & 83.7 & 78.7 & 73.6 & 65.2 & 44.9 & 35.4 & 34.3 & 33.7 & 21.9 \\
\hline $\begin{array}{l}\text { Percentage that do } \\
\text { not recognize }(\%)\end{array}$ & 0.6 & 4.5 & 9.6 & 15.2 & 16.3 & 21.3 & 26.4 & 34.8 & 55.1 & 64.6 & 65.7 & 66.3 & 78.1 \\
\hline
\end{tabular}


Table 3. The relationship between demographic factors and sustainability cue recognition.

\begin{tabular}{|c|c|c|c|c|}
\hline \multirow{2}{*}{$\begin{array}{l}\text { Sustainability cue and } \\
\text { overall percentage } \\
\text { recognition }(n=254)\end{array}$} & \multicolumn{4}{|c|}{ p value } \\
\hline & Gender (H1) & Age (H2) & Income (H3) & Education (H4) \\
\hline Fairtrade $(99.6 \%)$ & 0.513 & 0.884 & 0.496 & 0.540 \\
\hline 5-a-day $(94.9 \%)$ & 0.490 & 0.608 & 0.113 & 0.348 \\
\hline Red Tractor $(91.3 \%)$ & 0.441 & 0.183 & 0.071 & 0.125 \\
\hline Rainforest Alliance (85.8\%) & 0.138 & $0.019 *$ & 0.134 & $0.040 *$ \\
\hline $\operatorname{MSC}(85.4 \%)$ & 0.677 & 0.838 & 0.448 & 0.453 \\
\hline RSPCA $(80.3 \%)$ & 0.308 & 0.374 & 0.134 & 0.244 \\
\hline Soil Association $(73.6 \%)$ & 0.988 & $0.000 * * *$ & $0.006 * *$ & 0.163 \\
\hline Scotch Beef (64.6\%) & 0.759 & $0.006 *$ & 0.089 & 0.132 \\
\hline LEAF Marque (46.9\%) & 0.351 & 0.052 & 0.409 & $0.029 *$ \\
\hline Carbon Trust (38.6\%) & 0.110 & 0.175 & 0.251 & 0.294 \\
\hline Tesco Nurture $(35 \%)$ & 0.694 & 0.008 & 0.651 & $0.013 *$ \\
\hline BAP $(34.3 \%)$ & 0.780 & 0.087 & 0.690 & 0.379 \\
\hline UTZ (23.6) & 0.326 & 0.311 & 0.559 & 0.120 \\
\hline
\end{tabular}


Table 4. The influence of sustainability cues on IPI

\begin{tabular}{|c|c|c|c|c|c|c|c|c|c|c|c|c|c|}
\hline & 苞 & 莣 & 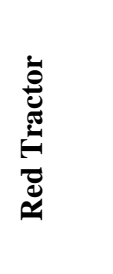 & 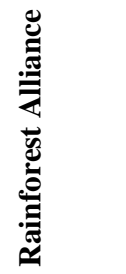 & 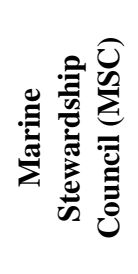 & 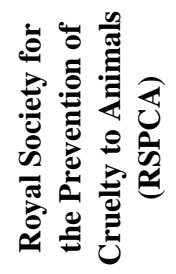 & 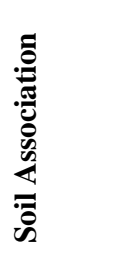 & 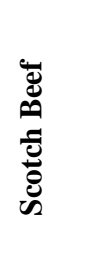 & 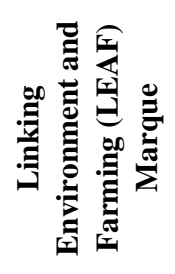 & 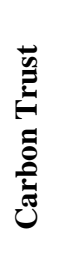 & 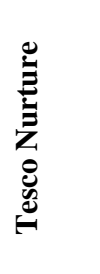 & 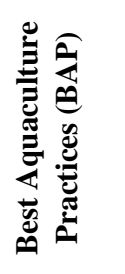 & $\stackrel{N}{S}$ \\
\hline $\begin{array}{l}\text { Male } \\
\text { percentage } \\
(\%)(n=76)\end{array}$ & 80.3 & 76.3 & 60.5 & 53.9 & 51.3 & 40.8 & 39.5 & 35.5 & 25.0 & 22.4 & 14.5 & 10.5 & 3.9 \\
\hline $\begin{array}{l}\text { Female } \\
\text { Percentage } \\
(\%)(\mathrm{n}=178)\end{array}$ & 80.3 & 82.0 & 69.7 & 65.2 & 59.6 & 60.7 & 42.7 & 32.6 & 19.1 & 23.6 & 11.2 & 11.2 & 6.2 \\
\hline
\end{tabular}


Table 5. The influence of sustainability cues that relate to IPB

\begin{tabular}{|c|c|c|c|c|c|c|c|c|c|c|c|c|c|}
\hline & 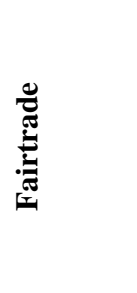 & 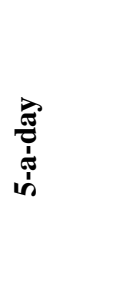 & 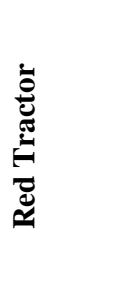 & 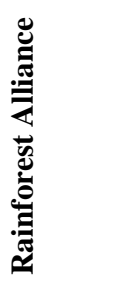 & 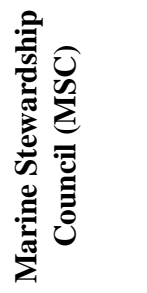 & 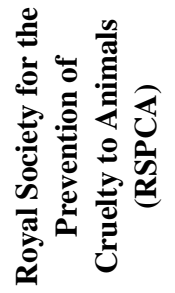 & 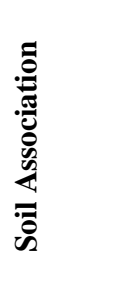 & 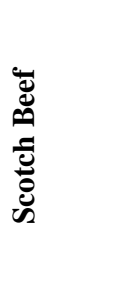 & 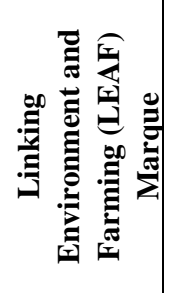 & 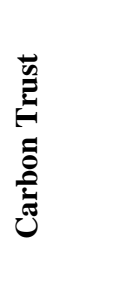 & 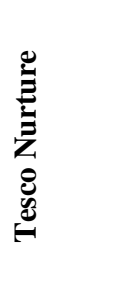 & 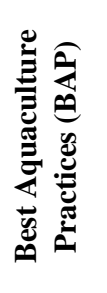 & $\stackrel{\mathbf{N}}{\mathbf{S}}$ \\
\hline $\begin{array}{l}\text { Male } \\
\text { percentage }(\%) \\
(\mathrm{n}=76)\end{array}$ & $21.1 \%$ & $13.2 \%$ & $13.2 \%$ & $9.2 \%$ & $7.9 \%$ & $5.3 \%$ & $3.9 \%$ & $1.3 \%$ & $1.3 \%$ & $1.3 \%$ & $0.0 \%$ & $0.0 \%$ & $0.0 \%$ \\
\hline $\begin{array}{l}\text { Female } \\
\text { Percentage } \\
(\%)(\mathrm{n}=178)\end{array}$ & $23.6 \%$ & $9.0 \%$ & $10.1 \%$ & $8.4 \%$ & $2.8 \%$ & $3.9 \%$ & $5.6 \%$ & $0.6 \%$ & $3.9 \%$ & $3.4 \%$ & $1.1 \%$ & $1.1 \%$ & $0.6 \%$ \\
\hline
\end{tabular}


Table 6. The relationship between demographic factors and IPB.

\begin{tabular}{|c|c|c|c|c|}
\hline \multirow{2}{*}{$\begin{array}{l}\text { Sustainability cue and } \\
\text { overall percentage } \\
\text { recognition }\end{array}$} & \multirow[b]{2}{*}{ Gender (H1) } & \multirow[b]{2}{*}{ Age (H2) } & \multirow[b]{2}{*}{ Income (H3) } & \multirow[b]{2}{*}{ Education (H4) } \\
\hline & & & & \\
\hline Fairtrade $(99.6 \%)$ & 0.315 & 0.754 & 0.580 & 0.155 \\
\hline 5-a-day $(94.9 \%)$ & 0.839 & 0.694 & 0.438 & $0.001 * * *$ \\
\hline Red Tractor $(91.3 \%)$ & 0.658 & 0.480 & 0.713 & 0.319 \\
\hline Rainforest Alliance (85.8\%) & 0.633 & 0.225 & 0.469 & 0.483 \\
\hline $\operatorname{MSC}(85.4 \%)$ & 0.478 & 0.855 & 0.321 & 0.815 \\
\hline RSPCA $(80.3 \%)$ & 0.580 & 0.937 & 0.168 & 0.596 \\
\hline Soil Association (73.6\%) & 0.068 & 0.303 & 0.945 & 0.392 \\
\hline Scotch Beef $(64.6 \%)$ & 0.274 & 0.069 & 0.226 & 0.486 \\
\hline LEAF Marque (46.9\%) & 0.360 & 0.114 & $0.006 * *$ & 0.373 \\
\hline Carbon Trust $(38.6 \%)$ & 0.534 & 0.107 & $0.004 * *$ & 0.488 \\
\hline Tesco Nurture $(35 \%)$ & 0.354 & 0.107 & 0.382 & 0.403 \\
\hline $\operatorname{BAP}(34.3 \%)$ & 0.354 & 0.321 & 0.382 & 0.403 \\
\hline UTZ (23.6) & 0.513 & 0.329 & 0.085 & 0.163 \\
\hline
\end{tabular}


Table 7. Chi- square test on gender groups and recognition, non-usage \& usage of cues

\begin{tabular}{|c|c|c|c|}
\hline \multirow[t]{2}{*}{ Logos } & \multicolumn{3}{|c|}{ Gender } \\
\hline & Pearson chi-square & Asympt. sig. & $\%$ cells - exp. Count less than 5 \\
\hline Fairtrade & 1.728 & 0.422 & $33.3 \%$ \\
\hline 5-a-day & 2.882 & 0.237 & $16.7 \%$ \\
\hline Red Tractor & 0.991 & 0.609 & $0.0 \%$ \\
\hline Rainforest Alliance & 6.864 & $0.032 * *$ & $0.0 \%$ \\
\hline MSC & 4.389 & 0.111 & $0.0 \%$ \\
\hline RSPCA & 18.158 & $0.000 * * *$ & $0.0 \%$ \\
\hline Soil Association & 0.316 & 0.854 & $0.0 \%$ \\
\hline Scotch Beef & 0.619 & 0.734 & $0.0 \%$ \\
\hline LEAF Marque & 1.743 & 0.418 & $0.0 \%$ \\
\hline Carbon Trust & 2.555 & 0.279 & $0.0 \%$ \\
\hline Tesco Nurture & 0.317 & 0.853 & $0.0 \%$ \\
\hline BAP & 1.577 & 0.454 & $0.0 \%$ \\
\hline UTZ & 2.570 & 0.277 & $16.7 \%$ \\
\hline
\end{tabular}




\begin{tabular}{|l|c|c|c|}
\hline \multirow{2}{*}{ Logos } & \multicolumn{2}{c|}{ Age } \\
\cline { 2 - 4 } & Pearson chi-square & Asympt. sig. & \% cells - exp. Count less than 5 \\
\hline Fairtrade & 1.901 & 0.754 & $33.3 \%$ \\
\hline 5-a-day & 5.557 & 0.235 & $22.2 \%$ \\
\hline Red Tractor & 7.332 & 0.119 & $11.1 \%$ \\
\hline Rainforest Alliance & 8.788 & 0.067 & $0.0 \%$ \\
\hline MSC & 4.394 & 0.355 & $0.0 \%$ \\
\hline RSPCA & 3.280 & 0.512 & $0.0 \%$ \\
\hline Soil Association & 32.895 & $0.000^{* * *}$ & $0.0 \%$ \\
\hline Scotch Beef & 15.461 & $0.004^{* * *}$ & $0.0 \%$ \\
\hline LEAF Marque & 5.025 & 0.285 & $0.0 \%$ \\
\hline Carbon Trust & 7.937 & 0.094 & $0.0 \%$ \\
\hline Tesco Nurture & 2.953 & 0.566 & $0.0 \%$ \\
\hline BAP & 9.959 & $0.041^{* *}$ & $0.0 \%$ \\
\hline UTZ & 7.588 & 0.108 & $22 \%$ \\
\hline
\end{tabular}

Table 9. Chi- square test on income groups and recognition, non-usage \& usage of cues 


\begin{tabular}{|l|c|c|c|}
\hline \multirow{2}{*}{ Logos } & \multicolumn{2}{c|}{ Income } \\
\cline { 2 - 4 } & Pearson chi-square & Asympt. sig. & \% cells - exp. Count less than 5 \\
\hline Fairtrade & 3.042 & 0.804 & $33.3 \%$ \\
\hline 5-a-day & 12.759 & 0.047 & $33.3 \%$ \\
\hline Red Tractor & 12.094 & 0.060 & $33.3 \%$ \\
\hline Rainforest Alliance & 7.692 & 0.262 & $8.3 \%$ \\
\hline MSC & 5.843 & 0.441 & $8.3 \%$ \\
\hline RSPCA & 4.793 & 0.571 & $0.0 \%$ \\
\hline Soil Association & 14.801 & $0.022 * *$ & $0.0 \%$ \\
\hline Scotch Beef & 7.494 & 0.278 & $0.0 \%$ \\
\hline LEAF Marque & 3.151 & 0.790 & $0.0 \%$ \\
\hline Carbon Trust & 4.793 & 0.571 & $8.3 \%$ \\
\hline Tesco Nurture & 3.425 & 0.754 & $16.7 \%$ \\
\hline BAP & 4.377 & 0.626 & $8.3 \%$ \\
\hline UTZ & 2.989 & 0.810 & $25.0 \%$ \\
\hline
\end{tabular}

Table 10. Kruskal-Wallis test on age and cues 


\begin{tabular}{|c|c|c|c|c|c|}
\hline \multirow[b]{2}{*}{ Logos } & Do not recognize it & Do not use it & Use it & & \\
\hline & Mean rank & Mean rank & Mean rank & $\mathrm{p}<0.05$ & Significant difference \\
\hline Soil Association & 95.40 & 129.02 & 146.63 & 0.000 & YES \\
\hline Carbon Footprint & 121.72 & 142.31 & 124.56 & 0.136 & NO \\
\hline UTZ & 127.16 & 132.01 & 117.39 & 0.789 & NO \\
\hline Scotch Beef & 107.31 & 128.80 & 147.68 & 0.001 & YES \\
\hline RSPCA & 118.38 & 128.15 & 130.47 & 0.585 & $\mathrm{NO}$ \\
\hline Rainforest Alliance & 157.58 & 116.22 & 125.71 & 0.015 & YES \\
\hline MSC & 121.03 & 120.60 & 130.82 & 0.571 & $\mathrm{NO}$ \\
\hline Red Tractor & 91.48 & 134.68 & 130.40 & 0.043 & YES \\
\hline Tesco Nurture & 124.67 & 132.08 & 134.18 & 0.683 & $\mathrm{NO}$ \\
\hline 5-a-Day & 129.73 & 136.83 & 122.32 & 0.317 & $\mathrm{NO}$ \\
\hline LEAF Marque & 123.43 & 128.58 & 135.70 & 0.537 & $\mathrm{NO}$ \\
\hline Fair Trade & 47.00 & 127.66 & 127.86 & 0.525 & $\mathrm{NO}$ \\
\hline BAP & 123.79 & 134.40 & 134.76 & 0.515 & $\mathrm{NO}$ \\
\hline
\end{tabular}

Table 11. Pairwise tests on age and cues

\begin{tabular}{|c|c|c|c|c|c|}
\hline Logos & Group & Mean rank & Group & Mean rank & $\mathrm{P}<0.05$ \\
\hline \multirow{2}{*}{ Soil Association } & \multirow[t]{2}{*}{ Do not recognize } & \multirow[t]{2}{*}{95.40} & Do not use it & 129.02 & 0.012 \\
\hline & & & Use it & 146.63 & 0.000 \\
\hline Scotch & Do not recognize & 107.31 & Use it & 147.68 & 0.001 \\
\hline \multirow[t]{2}{*}{ Rainforest Alliance } & \multirow[t]{2}{*}{ Do not recognize } & \multirow[t]{2}{*}{157.58} & Do not use it & 116.22 & 0.013 \\
\hline & & & Use it & 125.71 & 0.048 \\
\hline Red Tractor & Do not recognize & 91.48 & Use it & 130.40 & 0.044 \\
\hline
\end{tabular}


Table 12. Kruskal Wallis test on personal income and cues

\begin{tabular}{|c|c|c|c|c|c|}
\hline \multirow[b]{2}{*}{ Logos } & Do not recognize it & Do not use it & Use it & & \\
\hline & Mean rank & Mean rank & Mean rank & $\mathrm{P}<0.05$ & Significant difference \\
\hline Soil Association & 104.53 & 130.49 & 139.74 & 0.005 & YES \\
\hline Carbon Footprint & 120.56 & 140.56 & 134.21 & 0.126 & $\mathrm{NO}$ \\
\hline UTZ & 127.06 & 126.43 & 137.07 & 0.870 & $\mathrm{NO}$ \\
\hline Scotch Beef & 116.12 & 128.79 & 138.35 & 0.109 & $\mathrm{NO}$ \\
\hline RSPCA & 114.52 & 137.25 & 127.61 & 0.226 & $\mathrm{NO}$ \\
\hline Rainforest Alliance & 152.64 & 122.40 & 123.82 & 0.066 & $\mathrm{NO}$ \\
\hline MSC & 112.53 & 123.20 & 131.95 & 0.279 & $\mathrm{NO}$ \\
\hline Red Tractor & 106.48 & 148.66 & 126.86 & 0.056 & YES \\
\hline Tesco Nurture & 130.46 & 122.12 & 121.79 & 0.657 & NO \\
\hline 5-a-Day & 139.96 & 133.74 & 123.13 & 0.430 & $\mathrm{NO}$ \\
\hline LEAF Marque & 124.49 & 130.67 & 131.18 & 0.765 & $\mathrm{NO}$ \\
\hline Fair Trade & 36.50 & 129.21 & 127.53 & 0.424 & $\mathrm{NO}$ \\
\hline BAP & 127.15 & 126.24 & 129.41 & 0.973 & $\mathrm{NO}$ \\
\hline
\end{tabular}

Table 13. Pairwise tests on income and cues

\begin{tabular}{|c|c|c|c|c|c|}
\hline Logos & Group & Mean rank & Group & Mean rank & $\mathrm{P}<0.05$ \\
\hline Soil Association & Do not recognize & 104.53 & Use it & 139.74 & 0.004 \\
\hline Red Tractor & Do not recognize & 106.48 & Do not use it & 148.66 & 0.028 \\
\hline
\end{tabular}

867 
Table 14. Kruskal-Wallis test on education and cues

\begin{tabular}{|c|c|c|c|c|c|}
\hline & Do not recognize it & Do not use it & Use it & \\
\cline { 2 - 5 } Logos & Mean rank & Mean rank & Mean rank & P<0.05 & Significant difference \\
\hline Soil Association & 116.72 & 126.70 & 134.92 & 0.230 & NO \\
\hline Carbon Footprint & 129.22 & 125.33 & 123.55 & 0.873 & NO \\
\hline UTZ & 128.20 & 119.45 & 144.25 & 0.471 & NO \\
\hline Scotch Beef & 128.78 & 132.91 & 121.12 & 0.530 & NO \\
\hline RSPCA & 137.21 & 129.85 & 122.91 & 0.423 & NO \\
\hline Rainforest Alliance & 127.01 & 119.38 & 131.71 & 0.452 & NO \\
\hline MSC & 126.62 & 126.29 & 128.03 & 0.985 & NO \\
\hline Red Tractor & 105.64 & 163.96 & 124.85 & 0.005 & YES \\
\hline Tesco Nurture & 136.78 & 112.56 & 105.36 & 0.011 & \\
\hline 5-a-Day & 118.38 & 146.98 & 117.83 & 0.006 & YES \\
\hline LEAF Marque & 128.04 & 123.82 & 130.00 & 0.877 & YES \\
\hline Fair Trade & 142.50 & 137.71 & 124.97 & 0.490 & NO \\
\hline BAP & 130.84 & 123.86 & 119.58 & 0.540 & NO \\
\hline
\end{tabular}

Table 15. Pairwise tests on education and cues

\begin{tabular}{|c|c|c|c|c|c|}
\hline Logos & Group & Mean rank & Group & Mean rank & $\mathrm{P}<0.05$ \\
\hline \multirow{2}{*}{ Red Tractor } & Do not recognize & 105.64 & \multirow[t]{2}{*}{ Do not use it } & \multirow[t]{2}{*}{163.96} & 0.008 \\
\hline & Use it & 124.85 & & & 0.013 \\
\hline Nurture & Do not recognize & 136.78 & Do not use it & 112.56 & 0.053 \\
\hline 5-a-Day & Do not use it & 146.98 & Use it & 117.83 & 0.005 \\
\hline
\end{tabular}


Table 16. Demographic profiles of the four clusters

Increased recognition - generated by degree of recognition

881

\begin{tabular}{|c|c|c|c|c|}
\hline Cluster & 1 & 3 & 4 & 2 \\
\hline & $\begin{array}{l}\text { Low recognition, } \\
\text { low IPI }\end{array}$ & $\begin{array}{l}\text { Mixed } \\
\text { recognition - } \\
\text { but where } \\
\text { recognized } \\
\text { high IPI }\end{array}$ & $\begin{array}{l}\text { Aware but } \\
\text { low IPI }\end{array}$ & $\begin{array}{l}\text { Aware, with } \\
\text { high IPI }\end{array}$ \\
\hline$n=254$ & $71(28 \%)$ & $69(27.2 \%)$ & $56(22.8 \%)$ & $58(22 \%)$ \\
\hline \multicolumn{5}{|l|}{ Gender } \\
\hline Male & 28 & 6 & 19 & 23 \\
\hline Female & 43 & 63 & 37 & 35 \\
\hline \multicolumn{5}{|l|}{ Age } \\
\hline $18-34$ & 56 & 25 & 24 & 22 \\
\hline $35-54$ & 12 & 20 & 22 & 25 \\
\hline$>55$ & 3 & 24 & 10 & 11 \\
\hline \multicolumn{5}{|l|}{ Education } \\
\hline Secondary & 21 & 21 & 24 & 19 \\
\hline Undergraduate & 41 & 33 & 22 & 18 \\
\hline Postgraduate & 9 & 15 & 10 & 21 \\
\hline \multicolumn{5}{|l|}{ Income } \\
\hline$£ 0-19,999$ & 32 & 10 & 20 & 10 \\
\hline$£ 20,000-£ 39,999$ & 10 & 36 & 18 & 19 \\
\hline$£ 40,000-£ 74,999$ & 10 & 13 & 6 & 8 \\
\hline$£ 75,000$ & 20 & 10 & 12 & 21 \\
\hline
\end{tabular}




\begin{tabular}{|c|c|}
\hline $\begin{array}{l}\text { CARBON } \\
\text { TRUST } \\
.000\end{array}$ & $\begin{array}{l}\text { Carbon Trust } \\
\text { (Carbon Footprint) }\end{array}$ \\
\hline & $\begin{array}{l}\text { Fairtrade } \\
\text { (Fairness, communities and people welfare standard) }\end{array}$ \\
\hline $\begin{array}{l}\text { CERTIFIED } \\
\text { SUSAIANABLE } \\
\text { SEAFOOD } \\
\text { MSC } \\
\text { www.msc.org }\end{array}$ & $\begin{array}{l}\text { Marine Stewardship Council (MSC) } \\
\text { (Aquaculture standard) }\end{array}$ \\
\hline & $\begin{array}{l}\text { Soil Association } \\
\text { (Organic farm management standard) }\end{array}$ \\
\hline & $\begin{array}{l}\text { Rainforest Alliance } \\
\text { (Forest, landscape and communities standard) }\end{array}$ \\
\hline & $\begin{array}{l}\text { Linking Environment and Farming } \\
\text { (Farm management standard) }\end{array}$ \\
\hline & $\begin{array}{l}\text { Red Tractor } \\
\text { (Farm management standard and also designates } \\
\text { British provenance) }\end{array}$ \\
\hline & $\begin{array}{l}\text { RSPCA Assured } \\
\text { (Farm animal welfare standard) }\end{array}$ \\
\hline & $\begin{array}{l}\text { Scotch Beef } \\
\text { (Protected Geographic Indication (PGI) mark } \\
\text { identifying sourcing in Scotland, and farm } \\
\text { management standards) }\end{array}$ \\
\hline & $\begin{array}{l}\text { "5-A-Day" } \\
\text { (UK Government healthy eating logo representing a } \\
\text { portion of } 5 \text { x } 80 \mathrm{~g} \text { portions of fruit and vegetables } \\
\text { per day) }\end{array}$ \\
\hline & $\begin{array}{l}\text { Best Aquaculture Practices } \\
\text { (Aquaculture standard) }\end{array}$ \\
\hline & $\begin{array}{l}\text { UTZ } \\
\text { (Fair trade, community and human welfare standard) }\end{array}$ \\
\hline & $\begin{array}{l}\text { Tesco Nurture } \\
\text { (Tesco plc cue for fresh produce good agricultural } \\
\text { practice) }\end{array}$ \\
\hline
\end{tabular}

